\title{
Atlantis
}

Critical Studies in Gender, Culture \& Social Justice

Études critiques sur le genre, la culture, et la justice

\section{Why I Left My Book Club}

\section{Dorsía Smith Silva}

Volume 40, numéro 1, fall 2019

URI : https://id.erudit.org/iderudit/1066425ar

DOI : https://doi.org/10.7202/1066425ar

Aller au sommaire du numéro

Éditeur(s)

Mount Saint Vincent University

ISSN

1715-0698 (numérique)

Découvrir la revue

Citer ce document

Smith Silva, D. (2019). Why I Left My Book Club. Atlantis, 40(1), 69-69.

https://doi.org/10.7202/1066425ar d'utilisation que vous pouvez consulter en ligne.

https://apropos.erudit.org/fr/usagers/politique-dutilisation/ 


\section{Literary Work}

\section{Why I Left My Book Club}

I left my book club because I could no longer

hide behind the wide clear layers of privilege.

I no longer wanted to see the feigned ignorance of arched eyebrows

or hear nervous giggles when topics brushed past vanilla courtyards.

These women do not really want to know what I think.

Instead, they tell me to have a glass of wine and relax,

as if that would make me Dorothy:

three clicks of my ruby shoes and suddenly I am on the dirt road to oblivion.

No, I would rather be Red Riding Hood

who has found her way in the dense forest and has slain the big bad wolves-

turned those beasts into a new overcoat of her own choosing.

Dorsía Smith Silva is a Professor of English at the University of Puerto Rico, Río Piedras. Her poetry has been published in several journals and magazines in the United States and the Caribbean, including Portland Review, Saw Palm, Aji Magazine, Gravel, Adanna, Mom Egg Review, and POUI: Cave Hill Journal of Creative Writing. She is also the editor of Latina/Chicana Mothering and the co-editor of four books. 